\title{
Fæðuvenjur og fylgni við blóðprýsting meðal eldri Íslendinga
}

\author{
Atli Arnarson¹ næringarfræðingur, Ólöf Guơný Geirsdóttir²,5 næringarfræðingur, Alfons Ramel1,5 næringarfræðingur, Pálmi V. Jónsson², 3,4 læknir, \\ Laufey Steingrímsdóttir ${ }^{1,5}$ næringarfræðingur, Inga Pórsdóttir ${ }^{1,5}$ næringarfræðingur
}

\section{ÁGRIP}

Tilgangur: Tíoni langvinnra sjúkdóma, svo sem háprýstings, eykst með hækkandi aldri, en fæðuvenjur og aðrir lífsstílspættir geta haft áhrif á pessa próun. Par sem háprýstingur er einn helsti áhættupáttur hjarta- og æðasjúkdóma međal eldra fólks eru tengsl mataræđis og blóðprýstings mikilvægt rannsóknarefni. Tilgangur rannsóknarinnar var að kanna tengsl fæðupátta, sérstaklega lýsis, við blóðprýsting međal eldri Íslendinga á höfuðborgarsvæðinu og meta fæðuneyslu peirra með samanburði við íslenskar og norrænar ráđleggingar um mataræði og næringarefni. Efniviður og aðferðir: Pátttakendur voru 236 talsins, 65 til 91 árs gamlir Íslendingar af höfuðborgarsvæðinu. Níutíu og níu karlar (42\%) og 137 konur (58\%) tóku pátt. Mataræði peirra var metið með priggja daga veginni fæðuskráningu og blóðprýstingur mældur eftir 12 tíma föstu. Niðurstöður: Flestir pátttakendur fengu meira en lágmarksskammt af öllum nauð̌synlegum næringarefnum. Hins vegar fengu 19\% minna en lágmarksskammt af D-vítamíni, 13\% af joði, 17\% karla af B6-vítamíni, og 26\% karla og $12 \%$ kvenna af járni. Marktæk neikvæð fylgni var á milli lýsisneyslu og slagbilsprýstings. Pessi tengsl voru enn til staðar eftir að leiðrétt hafði verið fyrir aldri, pyngdarstuðli, kyni og inntöku á blóðprýstingslækkandi lyfjum ( $p=0,01)$. Neysla á löngum ómega-3 fitusýrum tengdist slagbilsprýstingi einnig marktækt. Ađ̛rir fæðupættir tengdust ekki blóðprýstingi.

Ályktanir: Niðurstöður benda til pess að neysla á lýsi sé tengd lægri blóðprýstingi meðal eldra fólks og hafi á pann hátt jákvæð áhrif á heilsufar. Stór hluti pátttakenda var í áhættuhópi vegna skorts á D-vítamíni, B6-vítamíni, jođi og járni.
${ }^{1}$ Rannsóknarstofu i næringarfræði Hí og Landspítala, rannsóknarstofu í öldrunarfræðum, ${ }^{3}$ æeknadeild Háskóla Íslands, ${ }^{4}$ öldrunarlækningadeild Landspítala, ${ }^{5}$ matvæla- og næringarfræðideild Hí.

Fyrirspurnir: Atli Arnarson atliarnar@gmail.com

Greinin barst: 8. maí 2012, sampykkt til birtingar: 13. ágúst 2012. gefin upp.

\section{Inngangur}

Tíðni langvinnra sjúkdóma eykst með hækkandi aldri en bættar fæðuvenjur og aðrir lífsstílspættir, eins og hreyfing, geta hægt á pessari próun. ${ }^{1}$

Háprýstingur er einn helsti áhættupáttur hjarta- og æðasjúkdóma meðal fullorðins fólks og par af leiðandi er mikilvægt og áhugavert að rannsaka tengsl mataræðis og blóðprýstings. ${ }^{2}$ Sterkar vísbendingar eru um að ákveðin næringarefni geti lækkað blóðprýsting meðal einstaklinga með háprýsting ef peirra er neytt reglulega í nægu magni í ákveðinn tíma. Dæmi um slíkt næringarefni eru langar ómega-3 fitusýrur (EPA og DHA) úr fiskiolíu. ${ }^{3}$ Neysla á fiskiolíu er tiltölulega mikil á Íslandi, og pá helst úr lýsi, en lýsisneysla er eitt af sérkennum íslensks mataræðis.

Mat á fæðuneyslu er nauðsynlegt til pess að hægt sé að greina tengsl mataræðis við heilsufarsbreytur og hvort ráðleggingum um mataræði sé fylgt. Markmið rannsóknarinnar var að meta fæðuneyslu eldra fólks á höfuðborgarsvæðinu og kanna tengsl einstakra fæðupátta við blóðprýsting, með sérstakri áherslu á lýsi. Megintilgátan var að fylgni væri á milli lýsisneyslu og lægri blóðprýstings. Petta er að öllum líkindum fyrsta rannsóknin sem skoðar tengsl mataræðis við blóðprýsting meðal eldri Íslendinga.

\section{Efniviður og aðferðir}

Rannsóknin er undirbáttur fæðuíhlutunarrannsóknar sem hönnuð var til pess að kanna áhrif mismunandi ípróttadrykkja á árangur styrktarpjálfunar eldri Íslendinga. Um er að ræða lýsandi áhorfsrannsókn (descriptive observational study) sem byggist á mælingum á mataræði og blóðprýstingi sem framkvæmdar voru við upphaf íhlutunarrannsóknarinnar. Í áhorfsrannsóknum er rannsóknarefnið skoðað og pví lýst án pess að rannsakendur hafi með einhverjum hætti áhrif á pað.

\section{Dátttakendur}

Pátttakendur voru 236 alls, 99 karlar (42\%) og 137 konur (58\%) á aldrinum 65 til 91 árs. Auglýst var eftir sjálfboðaliðum með pví að hengja upp veggspjöld á Hrafnistu í Hafnarfirði. Inntökuskilyrði voru pau að pátttakendur væru eldri en 65 ára og tækju ekki inn lyf sem hafa áhrif á vöðvamassa (testósterón, vefaukandi sterar, vaxtarhormón, eða IGF-1). Par að auki voru peir útilokaðir frá pátttöku sem höfðu litla vitsmunalega getu (MiniMental State Examination (MMSE) <19 stig) eða merki um kransæðasjúkdóm eða stoðkerfissjúkdóma, eins og gigt eða slit í liðum, sem hefðu mögulega haft áhrif á getu peirra til pess að ljúka pátttöku í rannsókninni.

\section{Mat á fæouneyslu}

Mataræði pátttakenda var metið með priggja daga veginni fæðuskráningu. Pátttakendur vigtuðu og skráðu alla neyslu matar og drykkjar í prjá daga samfleytt, tvo virka daga og einn helgardag. Munnlegar og skriflegar leiðbeiningar um vigtun fæðu voru gefnar pátttakendum og peir fengu rafvogir (PHILIPS HR 
Tafla I. Meðalgildi, \pm staðalfrávik, fyrir aldur, líkamspyngd $(\mathrm{kg})$, hæð $(\mathrm{cm})$, pyngdarstuðul (BMI, $\left.\mathrm{kg} / \mathrm{m}^{2}\right)$, orkuneyslu (kcal/dagur), grunnorkupörf (kcall dagur), og slag- og panbilsprýsting $(\mathrm{mmHg})$ fyrir alla pátttakendur $(n=236)$ Taflan sýnir einnig pann fjölda pátttakenda sem tók blóðprýstingslækkandi lyf.

\begin{tabular}{lcc}
\hline & Karlar & Konur \\
\hline Aldur, ár & $74,6 \pm 5,9$ & $72,8 \pm 5,9$ \\
\hline Pyngd, kg & $93,9 \pm 16,7$ & $74,6 \pm 13,1$ \\
\hline Hæð, cm & $177,5 \pm 7,6$ & $162,9 \pm 5,6$ \\
\hline BMl, kg/m² & $29,7 \pm 4,6$ & $28,1 \pm 4,9$ \\
\hline Grunnorkupörf, kcal/dag & $1741,3 \pm 264,5$ & $1329,6 \pm 137,0$ \\
\hline Slagbilsprýstingur, mmHg & $150,6 \pm 20,6$ & $139,8 \pm 18,2$ \\
\hline Panbilsprýstingur, mmHg & $77,9 \pm 10,1$ & $74,8 \pm 9,5$ \\
\hline Notkun hábrýstingslyfja, $\mathrm{n}$ & 60 & 64
\end{tabular}

2393) að láni. Niðurstöður fæðuskráningar voru færðar inn í vefforrit, byggðu á Íslenska gagnagrunninum um efnainnihald matvæla (ÍSGEM), sem reiknaði út næringarefnainnihald peirra matvæla og drykkjarfanga sem skráð voru.

Fæðuneysla og næringarefnainntaka var metin með samanburði við íslenskar og norrænar ráðleggingar ${ }^{4}$ um ráðlagðan dagsskammt, meðalpörf, lágmarksskammt, hámarksskammt, auk orkuprósentu fyrir orkugefandi næringarefni. Ráðlagður dagsskammtur af næringarefni uppfyllir næringarpörf langflestra fyrir viðkomandi efni, eða um 97-98\% heilbrigðs fólks. Með næringarpörf er átt við að næringarefnið geti sinnt hlutverki sínu fyrir starfsemi líkamans og auk pess viðhaldið eðlilegum birgðum hans. Meðalpörf ákveðins næringarefnis uppfyllir pörf 50\% einstaklinga. Lágmarksskammtur segir til um minnsta magn sem kemur í veg fyrir skortseinkenni eða hörgulsjúkdóm. Sáhluti hópsins sem neytir minna magns af næringarefni en lágmarkspörf segir til um, á pess vegna á hættu að skortseinkenni komi fram. Hámarksskammtur af næringarefni er örugg neysla fyrir langflesta, eða um pað bil 97-98\% fólks, án ofhleðslu eða eitrunareinkenna. Hluti hópsins sem neytir meira magns af tilteknu næringarefni en hámarkspörf segir til um, getur fengið eitrunareinkenni ef neysla er lengi svo há. ${ }^{4}$ Orkuprósenta orkugefandi næringarefnis er skilgreind sem hlutfall orku úr tilteknu næringarefni af heildarorkuinntöku.

\section{Mælingar á blóðprýstingi}

Eftir 12 tíma föstu við upphaf rannsóknar var blóðprýstingur mældur að morgni með sjálfvirkum blóðprýstingsmæli fyrir upphandlegg, Medisana S1000 (Medisana AG, Neuss, Pýskalandi). Allar mælingar á blóðprýstingi voru framkvæmdar af hjúkrunarfræðingi á meðan pátttakandi sat kyrr og afslappaður í uppréttri setu og hvíldi hægri upphandlegg á borðbrún með olnbogabót í hjartahæð. Tveir hjúkrunarfræðingar önnuðust mælingar í rannsókninni. Tvær mælingar voru gerðar með tveggja mínútna millibili og meðaltal peirra reiknað út. Ef munur á mælingunum tveimur var meiri en $10 \mathrm{mmHg}$, var priðja mælingin framkvæmd og meðaltal priggja mælinga notað. Fyrsta stigs háprýstingur var skilgreindur sem slagbilsprýstingur (SBP) $\geq 140 \mathrm{mmHg}$ og/eða panbilsprýstingur ( $\mathrm{PBP}) \geq 90 \mathrm{mmHg}$. Einangraður slagbilsháprýstingur var skilgreindur sem $\mathrm{SBP} \geq 140 \mathrm{mmHg}$ og $\mathrm{PBP}<90 \mathrm{mmHg}$, og einangraður panbilsháprýstingur sem SBP $<140$ og $\mathrm{PBP} \geq 90.5,6$ Pátttakendur
Tafla II. Meðalneysla, \pm staðalfrávik, valinna næringarefna, vítamína, steinefna og fæðuflokka ( $n=160)$. Orkuprósenta orkugefandi næringarefna $(E \%)$ er einnig sýnd.

\begin{tabular}{|c|c|c|}
\hline & Karlar & Konur \\
\hline \multicolumn{3}{|l|}{ Næringarefni } \\
\hline D vítamín, $\mu \mathrm{g} / \mathrm{dag}$ & $11,3 \pm 11,3$ & $15,2 \pm 18,6$ \\
\hline C vítamín, mg/dag & $87,6 \pm 51,0$ & $89,2 \pm 56,2$ \\
\hline B6 vítamín, mg/dag & $1,9 \pm 0,8$ & $1,5 \pm 0,6$ \\
\hline Fólasín, $\mu \mathrm{g} / \mathrm{dag}$ & $269,2 \pm 125,5$ & $233,6 \pm 95,5$ \\
\hline Kalk, mg/dag & $946,0 \pm 375,2$ & $814,8 \pm 220,7$ \\
\hline Magnesíum, mg/dag & $290,5 \pm 73,0$ & $252,2 \pm 56,4$ \\
\hline Joð, $\mu g / d a g$ & $211,7 \pm 135,0$ & $170,5 \pm 123,9$ \\
\hline Járn, mg/dag & $11,0 \pm 5,9$ & $8,7 \pm 4,2$ \\
\hline Salt, g/dag & $6,9 \pm 2,0$ & $5,7 \pm 1,6$ \\
\hline Alkóhól, g/dag & $6,9 \pm 12,0$ & $3,2 \pm 5,4$ \\
\hline Prótein, g/kg/dag & $1,0 \pm 0,2$ & $1,0 \pm 0,2$ \\
\hline Prótein, E\% & $18,8 \pm 3,8$ & $18,0 \pm 3,1$ \\
\hline Fita, E\% & $37,0 \pm 7,0$ & $37,3 \pm 5,8$ \\
\hline Kolvetni, E\% & $40,1 \pm 6,2$ & $41,5 \pm 5,3$ \\
\hline Unninn sykur, E\% & $6,9 \pm 3,6$ & $7,1 \pm 3,8$ \\
\hline Trefjar, E\% & $1,8 \pm 0,5$ & $2,0 \pm 0,6$ \\
\hline Langar ómega-3 fitusýrur, g/dag & $1,3 \pm 1,2$ & $1,5 \pm 1,8$ \\
\hline \multicolumn{3}{|l|}{ Fæðuflokkar og matvæli, g/dag } \\
\hline Mjólkurvörur & $308,7 \pm 219,7$ & $270,0 \pm 150,5$ \\
\hline Ostar & $31,9 \pm 25,7$ & $31,3 \pm 24,7$ \\
\hline Fiskur & $98,0 \pm 71,0$ & $71,9 \pm 47,5$ \\
\hline Lýsi & $3,77 \pm 4,62$ & $4,82 \pm 5,45$ \\
\hline Ávextir og grænmeti & $207,8 \pm 168,6$ & $230,0 \pm 145,2$ \\
\hline Ávextir & $107,0 \pm 115,0$ & $127,3 \pm 115,2$ \\
\hline Grænmeti & $100,8 \pm 83,6$ & $102,7 \pm 71,7$ \\
\hline
\end{tabular}

voru fastandi og höfðu ekki tekið inn blóðprýstingslækkandi lyf fyrir mælinguna. Blóðprýstingslækkandi lyf voru skilgreind sem lyf í ATC-flokkum C02-C04 og C07-C09.

\section{Vanskráning}

Til pess að minnka skekkjur voru peir sem vanskráðu mataræði ekki hafðir með í útreikningum. Vanskráning var metin út frá orkuinntöku, grunnorkupörf og hreyfistuðli (physical activity level) með pví að nota formúlu sem nefnd hefur verið Goldberg-stýfing tvö (Goldberg cut-off 2).-9 Formúlan gefur pað hlutfall orkuinntöku og orkuparfar sem talið er lágmark til að viðhalda eðlilegu lífi. Pátttakendur sem voru fyrir neðan petta hlutfall eða stýfingarmark (cut-off limit) voru taldir hafa vanskráð mataræðið.

Hreyfistuðullinn 1,58 var fenginn út frá viðmiðunargildum fyrir sama aldurshóp sem byggð eru á efnaskiptarannsóknum sem notast hafa við tvímerkt vatn. ${ }^{8}$ Grunnorkupörf var reiknuð út með Harris-Benedict-jöfnunni. ${ }^{10}$ Leiðrétt var fyrir fitumassa með pví að nota 50\% leiðréttingarpátt hjá offeitum einstaklingum (pyngdarstuðull $\geq 30 \mathrm{~kg} / \mathrm{m}^{2}$ ). Við leiðréttingu var eftirfarandi formúla notuð til pess að reikna út pyngd sem síðan var sett í Harris-Benedict- 
Tafla III. Ráðlagður dagsskammtur og viðmiðunargildi fyrir vitamín og steinefni samkvæmt Norrænu ráðleggingunum um mataræði og næringarefni ${ }^{4}$ (n=160). Prósenta pátttakenda undir eða yfir lágmarkspörf (LP), meðalpörf (MP), ráðlögðum dagsskammti (RDS), og hámarkspörf (HP) er einnig sýnd.

\begin{tabular}{|c|c|c|c|c|c|c|c|c|c|}
\hline & & \multicolumn{4}{|c|}{ Viðmiðunargildi } & \multirow{2}{*}{$\begin{array}{c}<\mathrm{LP} \\
\%\end{array}$} & \multirow{2}{*}{$\begin{array}{c}<\mathrm{MP} \\
\%\end{array}$} & \multirow{2}{*}{$\frac{>\text { RDS }}{\%}$} & \multirow{2}{*}{$\frac{>\mathrm{HP}}{\%}$} \\
\hline & & LP & $\mathrm{MP}$ & RDS & $\mathrm{HP}$ & & & & \\
\hline \multirow{2}{*}{ D-vítamín, $\mu \mathrm{g} / \mathrm{dag}$} & Karlar & 2,5 & - & 15 & 50 & 18 & - & 29 & 3 \\
\hline & Konur & 2,5 & - & 15 & 50 & 20 & - & 40 & 5 \\
\hline \multirow{2}{*}{ C-vítamín, mg/dag } & Karlar & 10 & 60 & 75 & 1000 & 2 & 36 & 58 & 0 \\
\hline & Konur & 10 & 50 & 75 & 1000 & 1 & 40 & 55 & 0 \\
\hline \multirow{2}{*}{ B6-vítamín, mg/dag } & Karlar & 1 & 1,3 & 1,6 & 25 & 17 & 23 & 62 & 0 \\
\hline & Konur & 0,8 & 1,0 & 1,2 & 25 & 4 & 19 & 67 & 0 \\
\hline \multirow{2}{*}{ Fólasín, $\mu \mathrm{g} / \mathrm{dag}$} & Karlar & 100 & 200 & 300 & 1000 & 3 & 29 & 32 & 0 \\
\hline & Konur & 100 & 200 & 300 & 1000 & 0 & 45 & 16 & 0 \\
\hline \multirow{2}{*}{ Kalk, mg/dag } & Karlar & 400 & - & 800 & 2500 & 3 & - & 58 & 0 \\
\hline & Konur & 400 & - & 800 & 2500 & 2 & - & 46 & 0 \\
\hline \multirow{2}{*}{ Magnesíum, mg/dag } & Karlar & - & - & 350 & - & - & - & 21 & - \\
\hline & Konur & - & - & 280 & - & - & - & 31 & - \\
\hline \multirow{2}{*}{ Joð, $\mu \mathrm{g} / \mathrm{dag}$} & Karlar & 70 & 100 & 150 & 600 & 12 & 20 & 65 & 2 \\
\hline & Konur & 70 & 100 & 150 & 600 & 13 & 31 & 44 & 1 \\
\hline \multirow{2}{*}{ Járn, mg/dag } & Karlar & 7 & 7 & 9 & 25 & 26 & 26 & 52 & 6 \\
\hline & Konur & 5 & 6 & 9 & 25 & 12 & 23 & 34 & 2 \\
\hline
\end{tabular}

jöfnuna: (Raunveruleg líkamspyngd - ákjósanleg líkamspyngd) x 0,5 + ákjósanleg líkamspyngd. ${ }^{11}$ Ákjósanleg líkamspyngd var reiknuð með Robinson-formúlunni. ${ }^{12}$

\section{Tölfræðiúrvinnsla}

Gögn voru færð inn í tölfræðiforritið SPSS, útgáfu 20,0 (SPSS, Chicago, IL, USA). Niðurstöðum er lýst sem meðaltali \pm staðalfrávik. Tölfræðileg marktækni miðast við P-gildi $<0,05$. Spearmaneða Pearson-fylgnigreiningar voru notaðar til pess að reikna út einfalda fylgni. Fervikagreining var notuð til pess að kanna tengsl á milli fæðuneyslu og blóðprýstings. Leiðréttingapættir í fervikagreiningu voru eftirfarandi: aldur og pyngdarstuðull (hjábreytur), og kyn og inntaka á blóðprýstingslækkandi lyfjum (bundnir pættir). Öll gögn uppfylltu forsendur peirra tölfræðiprófa sem notuð voru.

\section{Leyfi}

Vísindasiðanefnd (VSNb2008060007/03-15) og Persónuvernd (S4018/2008) veittu leyfi fyrir rannsókninni, sem fylgdi reglum Helsinki-yfirlýsingarinnar. Allir pátttakendur gáfu upplýst sampykki.

\section{Niðurstöður}

Niðurstöður í töflum II-VI byggjast á gögnum frá 160 pátttakendum, 65 körlum og 95 konum. Prjátíu og fjórir pátttakendur skiluðu ekki fæðudagbókum eða fylltu pær út á rangan hátt (14\%) og 42 vanskráðu fæðuneyslu samkvæmt Goldberg-stýfingu tvö (18\%). Hlutfall orkuinntöku og orkuparfar undir 0,95 taldist vanskráning. Skráð orku- og næringarefnainntaka var marktækt lægri meðal peirra sem vanskráðu, en annars var ekki marktækur munur á líkamspyngd, hæð, grunnefnaskiptahraða eða annarra pátta á milli peirra sem vanskráðu og annarra.
Tafla I sýnir meðalgildi ( \pm staðalfrávik) fyrir aldur, líkamspyngd $(\mathrm{kg})$, hæð (cm), pyngdarstuðul (BMI, $\left.\mathrm{kg} / \mathrm{m}^{2}\right)$, orkuneyslu (kcal/dag), grunnorkupörf (kcal/dag), og slag- og panbilsprýsting $(\mathrm{mmHg})$ fyrir alla pátttakendur $(\mathrm{n}=236)$.

Hlutfall karla með háprýsting (76\%) var mun hærra en kvenna (42\%). Einangraður slagbilsháprýstingur var algengasta gerð háprýstings, á meðan samanlagður slagbilsháprýstingur og panbilsháprýstingur var mun sjaldgæfari. Enginn pátttakandi greindist með einangraðan panbilsháprýsting.

Marktæk fylgni var á milli lýsisneyslu (g/dag) og slagbilsprýstings, samkvæmt Spearman-fylgniprófi $(\rho=-0,201, \mathrm{P}=0,012)$. Aðrir fæðupættir tengdust blóðprýstingi ekki marktækt eftir að tekið hafði verið tillit til kynjamunar.

Tafla II sýnir neyslu orkuefna og valinna vítamína og steinefna, auk flokka matvæla.

Tafla III sýnir ráðlagða dagsskammta, lágmarksskammt, meðalpörf, og hámarksskammt af næringarefnum og steinefnum. Af vítamínum og steinefnum reyndist neysla á D-vítamíni oftast vera minni en ráðleggingar tiltóku, 18\% karla og 20\% kvenna fengu minna en lágmarksskammt af D-vítamíni. Jákvæð fylgni var á milli neyslu D-vítamíns og lýsisneyslu $(\rho=0,731, P<0,001)$ en $56 \%$ pátttakenda neyttu lýsis.

Tafla IV sýnir ráðlagða orkuprósentu fyrir orkugefandi næringarefni, ráðleggingar um fæðuval, og hlutfall pátttakenda með neyslu innan ráðlagðs dagskammts. Próteinneysla var nokkuð mikil hjá stærstum hluta pátttakenda, samanborið við ráðlagða neyslu fyrir eldra fólk ( $\geq 65$ ára), 1,0 g á hvert kg líkamspyngdar á dag, ${ }^{4}$ en $41 \%$ karla og $47 \%$ kvenna fylgdu ráðleggingum um próteinneyslu. Stórt hlutfall karla (46\%) og kvenna (37\%) neyttu meira en ráðlagðs dagsskammts af salti, og $65 \%$ karla og 51\% kvenna náði ekki ráðlagðri orkuprósentu af trefjaefnum. Fáir pátttakendur neyttu nægilega mikils af ávöxtum, grænmeti og mjólkurvörum en fiskneysla var hins vegar næg hjá flestum. 
Tafla IV. Fremri dálkur sýnir ráðleggingar um neyslu salts, orkuefna og fæðuflokka $(R)$, eða ráðlagða orkuprósentu orkugefandi næringarefna (E\%) fyrir eldra fólk ( 265 ára) samkvæmt Norrænu ráđleggingunum um mataræði og næringarefni. ${ }^{4}$ Seinni dálkur sýnir prósentu pátttakenda $(n=160)$ sem fylgdu rádleggingum.

\begin{tabular}{|c|c|c|c|}
\hline & & R eða $E \%$ & \% sem fylgdu R eða E\% \\
\hline \multicolumn{4}{|c|}{ Salt, orkuefni og trefjar } \\
\hline Salt, g/dag & Karlar / Konur & $<7 /<6$ & $55 / 63$ \\
\hline Alkóhól, g/dag & Karlar / Konur & $<20 /<10$ & $89 / 86$ \\
\hline Prótein, $\mathrm{g} / \mathrm{kg} / \mathrm{dag}$ & Karlar / Konur & $>1,0$ & $41 / 47$ \\
\hline Prótein, E\% & Karlar / Konur & $10-20$ & $61 / 75$ \\
\hline Fita, E\% & Karlar / Konur & $25-35$ & $41 / 33$ \\
\hline Kolvetni, E\% & Karlar / Konur & $50-60$ & $5 / 3$ \\
\hline Unninn sykur, E\% & Karlar / Konur & $<10$ & $77 / 78$ \\
\hline Trefjar, E\% & Karlar / Konur & $>2$ & $35 / 49$ \\
\hline \multicolumn{4}{|l|}{ Fæðuflokkar, g/dag } \\
\hline Mjólkurvörur & Karlar / Konur & 500 & $18 / 9$ \\
\hline Fiskur & Karlar / Konur & $>43$ & $79 / 71$ \\
\hline Ávextir og grænmeti & Karlar / Konur & $>400$ & $15 / 12$ \\
\hline Ávextir & Karlar / Konur & $>200$ & $14 / 25$ \\
\hline Grænmeti & Karlar / Konur & $>200$ & $15 / 11$ \\
\hline
\end{tabular}

Tafla V sýnir mun á panbils- og slagbilsprýstingi á milli priðjungsmarka lýsisneyslu (g/dag) og neyslu á löngum ómega-3 fitusýrum (g/dag), bæði hjá körlum og konum ( $n=160)$, eins og hann var metinn með fervikagreiningu. Samkvæmt fervikagreiningu hélst marktækt neikvætt samband á milli slagbilsprýstings og lýsisneyslu $(\mathrm{P}=0,010)$ og neyslu á löngum ómega-3 fitusýrum $(\mathrm{P}=0,029)$ pegar neðstu og efstu priðjungsmörk neyslu voru borin saman, jafnvel pó leiðrétt hafi verið fyrir kyni, aldri, pyngdarstuðli, og inntöku á blóðprýstingslækkandi lyfjum. Neikvæð tengsl fundust jafnframt á milli panbilprýstings og neyslu á löngum ómega-3 fitusýrum. Hreyfing í frístundum, mæld í mínútum á dag, og reykingar nú eða áður, tengdust ekki blóðprýstingi eða mataræði marktækt og höfðu ekki áhrif á sambandið milli blóðprýstings og neyslu lýsis eða langra ómega-3 fitusýra pegar leiðrétt var fyrir peim í fervikagreiningu. Auk pess hafði leiðrétting með blóðfitum (kólesteróli, HDL eða príglýseríðum) ekki áhrif á petta samband (niðurstöður ekki sýndar).

Tafla VI sýnir meðalneyslu lýsis (g/dag) og langra ómega-3 fitusýra (g/dag), innan priðjungsmarka neyslu, samkvæmt priggja daga veginni fæðuskráningu.

Tafla VI. Meðalneysla lýsis (g/dag) og langra ómega-3 fitusýra (g/dag), innan priðjungsmarka neyslu, samkvæmt priggja daga veginni fæðuskráningu $(n=160)$.

\begin{tabular}{lcc} 
& Lýsi & Langar ómega-3 fitusýrur \\
\hline Fyrstu priðjungsmörk & $0 \pm 0$ & $0,3 \pm 0,2$ \\
\hline Önnur priðjungsmörk & $3,6 \pm 1,2$ & $1,0 \pm 0,3$ \\
\hline Priðju priðjungsmörk & $10,4 \pm 3,7$ & $3,1 \pm 1,8$ \\
\hline
\end{tabular}

Tafla V. Munur á panbils- og slagbilsprýstingi á milli priðjungsmarka á lýsisneyslu (g/dag) og neyslu á löngum ómega-3 fitusýrum (g/dag), metinn með fervikagreiningu. Leiðréttingarpættir voru aldur og pyngdarstuðull (hjábreytur), og kyn og inntaka á blóðprýstingslækkandi lyfjum (bundnir pættir). Útreikningarnir byggjast á gögnum frá 160 pátttakendum.

\begin{tabular}{|c|c|c|c|c|}
\hline & \multirow{2}{*}{$\begin{array}{l}\text { Munur frá fyrstu } \\
\text { priðjungsmörkum } \\
\text { B }\end{array}$} & \multicolumn{3}{|c|}{ 95\% öryggisbil } \\
\hline & & Lægri & Efri & $P$ \\
\hline \multicolumn{5}{|l|}{ Slagbilsprýstingur } \\
\hline \multicolumn{5}{|l|}{ Lýsi } \\
\hline Önnur priðjungsmörk & $-5,81$ & $-12,81$ & 1,20 & 0,104 \\
\hline Priðju priðjungsmörk & $-7,90$ & $-13,86$ & $-1,95$ & 0,010 \\
\hline \multicolumn{5}{|l|}{ Langar ómega-3 fitusýrur } \\
\hline Önnur priðjungsmörk & $-9,80$ & $-16,58$ & $-3,02$ & 0,005 \\
\hline Priðju priðjungsmörk & $-7,53$ & $-14,27$ & $-0,79$ & 0,029 \\
\hline \multicolumn{5}{|l|}{ Panbilsprýstingur } \\
\hline \multicolumn{5}{|l|}{ Lýsi } \\
\hline Önnur priðjungsmörk & $-1,11$ & $-4,85$ & 2,63 & 0,559 \\
\hline Priðju priðjungsmörk & $-1,58$ & $-4,76$ & 1,60 & 0,327 \\
\hline \multicolumn{5}{|l|}{ Langar ómega-3 fitusýrur } \\
\hline Önnur priðjungsmörk & $-4,90$ & $-8,20$ & $-1,60$ & 0,004 \\
\hline Priðju priðjungsmörk & $-3,61$ & $-6,89$ & $-0,33$ & 0,031 \\
\hline
\end{tabular}

\section{Umræða}

Aðalmarkmið rannsóknarinnar var að skoða tengsl mataræðis og blóðprýstings, með áherslu á lýsisneyslu, og að kanna fylgni fæðupátta við íslenskar og norrænar ráđleggingar um næringarefni og mataræði. Petta er að öllum líkindum fyrsta rannsóknin sem skoðar tengsl mataræðis við blóðprýsting Íslendinga, 65 ára og eldri.

Marktæk neikvæð fylgni var á milli lýsisneyslu og slagbilsprýstings, jafnvel pegar leiðrétt var fyrir kyni, aldri, pyngdarstuðli og inntöku á blóðprýstingslækkandi lyfjum. Samskonar tengsl sáust pegar langar ómega-3 fitusýrur voru skoðaðar. Marktæk neikvæð fylgni var einnig á milli neyslu á löngum ómega-3 fitusýrum og panbilsprýstings, en marktæk tengsl fundust hins vegar ekki á milli lýsisneyslu og panbilsprýstings. Óljóst er hvers vegna lýsisneysla tengdist panbilsprýstingi ekki marktækt eins og neysla langra ómega-3 fitusýra. Ástæðan er hugsanlega sú að lýsi inniheldur ekki einungis langar ómega-3 fitusýrur (EPA og DHA) heldur einnig mörg önnur næringarefni sem gætu hafa veikt sambandið.

Pó niðurstöður rannsókna séu ekki samhljóma, bendir flest til pess að mikil neysla langra ómega-3 fitusýra ( $\geq 3 \mathrm{~g} / \mathrm{dag}$ ) hafi væg en marktæk áhrif til lækkunar blóðprýstings, sérstaklega meðal aldraðra og fólks með háprýsting., ${ }^{3,13}$ Niðurstöður pessarar rannsóknar benda til pess sama, pó ekki sé hægt að fullyrða að um beint orsakasamband sé að ræða. Hins vegar má telja líklegt að lýsisneysla, eða neysla annarra fæðubótarefna sem innihalda fiskiolíur, lækki blóðprýsting meðal eldra fólks og hafi á pann hátt jákvæð áhrif á heilsufar. Pó er rétt að fara varlega í að yfirfæra pessar niðurstöður á aðra hópa. Íslensk rannsókn frá árinu 2006 bendir til pess að áhrif fiskiolía á blóðprýsting séu pveröfug meðal barnshafandi kvenna, en par fannst jákvætt samband á milli neyslu á löngum ómega-3 fitusýrum, aðallega úr lýsi, og háprýstings. ${ }^{14}$ 
Fæðuneysla var í flestum tilfellum í samræmi við niðurstöður Könnunar á mataræði Íslendinga, ${ }^{15}$ sem gefur til kynna að mataræði pátttakenda hafi ekki verið verulega frábrugðið mataræði annarra Íslendinga í sama aldurshópi.

Nokkur kynjamunur kom fram í rannsókninni. Neysla á mörgum vítamínum og steinefnum var hærri meðal karla en kvenna og endurspeglast pað í meiri orkuinntöku meðal karla (2042 kcal/d) samanborið við konur (1662 kcal/d).

Neysla undir lágmarksskammti var sjaldgæf pegar kom að vítamínum og steinefnum. Af peim vítamínum og steinefnum sem könnuð voru var lítil neysla D-vítamíns algengust par sem 19,3\% pátttakenda fengu minna en lágmarksskammt. Jákvæð fylgni var á milli D-vítamínneyslu og lýsisneyslu og flestir pátttakendur sem fengu minna en lágmarksskammt $(<2,5 \mu \mathrm{g} / \mathrm{d})$ tóku ekki inn lýsi. Fæðutegundir sem ríkar eru af D-vítamíni eru fáar og ónóg D-vítamínneysla er pess vegna vel pekkt vandamál. ${ }^{16}$

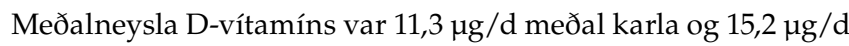
meðal kvenna. Í sama aldurshópi ( $\geq 65$ ára) í Könnun á mataræði Íslendinga var meðalneysla 12,9 $\mu \mathrm{g} / \mathrm{d}$ meðal karla og 8,4 $\mu \mathrm{g} / \mathrm{d}$ meðal kvenna. ${ }^{15}$ Í breskri neyslukönnun á sama aldurshópi voru

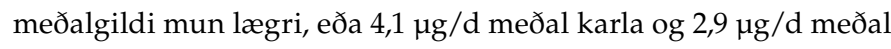
kvenna. ${ }^{16}$ Líklegt er að pessi munur sé tilkominn vegna pess hve lýsisneysla er útbreidd á Íslandi.

Neysla B6-vítamíns var að meðaltali 1,9 mg/d meðal karla og $1,5 \mathrm{mg} / \mathrm{d}$ meðal kvenna. Mun fleiri karlar en konur fengu minna en lágmarksskammt af B6-vítamíni, eða um 17\%, samanborið við $4 \%$ hjá konum. Pessi munur endurspeglar að einhverju leyti hærri ráðlagðan dagsskammt B6-vítamíns fyrir karla. Talsverður hluti pátttakenda fékk minna en lágmarksskammt af joði, eða 12\% meðal karla og 13\% meðal kvenna. Einnig fékk 26\% karla minna en lágmarksskammt af járni og 12\% kvenna. Hærri lágmarkspörf meðal karla (7 mg/d) samanborið við konur (5 mg/d) gæti skýrt pennan kynjamun. Kjöt er rík uppspretta af járni og B6-vítamíni og neysla pessara tveggja næringarefna helst pví oft í hendur.

Próteinneysla var að meðaltali $1,0 \mathrm{~g} / \mathrm{kg} / \mathrm{dag}$ og um $45 \%$ pátttakenda uppfylltu ráðlagða neyslu próteina $(1,0 \mathrm{~g} / \mathrm{kg} / \mathrm{d})$ fyrir aldraða. ${ }^{4}$ Neysla á próteinum virðist að jafnaði hafa verið nægjanleg (83\%), ef hún er miðuð við núverandi ráðleggingar fyrir fullorðna, 0,8 g á kg líkamspyngdar á dag. ${ }^{4}$

Neysla á próteinum, í prósentum af heildarorkuneyslu, var oftast í takt við ráðleggingar. Engir pátttakendur voru fyrir neðan ráðlagða orkuprósentu próteina, en 30\% pátttakenda voru yfir ráðlagðri prósentu. Orkuprósenta fitu var yfir ráðleggingum meðal $60 \%$ pátttakenda. Mikil neysla fitu og próteina gerir pað að verkum að orkuprósenta kolvetna lækkar. Aðeins 3,8\% pátttakenda voru innan ráðlegginga fyrir kolvetni og engir yfir ráðlagðri orkuprósentu. Trefjaneysla var einnig minni en ráðleggingar segja til um hjá flestum pátttakendum (56,9\%), sem endurspeglar að öllum líkindum litla neyslu kolvetna.

Margir pátttakendur voru yfir ráðleggingum fyrir saltneyslu, $45,5 \%$ karla og 37,2\% kvenna. Raunveruleg saltneysla er hins vegar líkleg til að vera talsvert hærri, par sem salt er oft notað við eldamennsku og ekki skráð.

Neysla fiskmetis var næg meðal flestra pátttakenda. Ávaxta- og grænmetisneysla var hins vegar minni en tiltekið er í ráðleggingum meðal 25\% pátttakenda. Algengt er að neysla ávaxta og grænmetis sé minni en ráðleggingar segja meðal eldra fólks á Íslandi og í öðrum löndum. . $5,17^{2}$

Mat á fæðuneyslu tók ekki með í reikninginn inntöku á fæðubótarefnum, öðrum en lýsi, vegna skorts á upplýsingum um næringarefnainnihald fæðubótarefna í Íslenska gagnagrunninum um efnainnihald matvæla. Vítamín tóku 43\% pátttakenda og 17\% pátttakenda náttúrulyf og/eða náttúruefni. Rannsóknin var sambærileg Könnun á mataræði Íslendinga að pví leyti að hún tók ekki tillit til neyslu næringarefna úr fæðubótarefnum, öðrum en lýsi.

Brottfall var 14\% par sem nokkur fjöldi pátttakenda skilaði ekki matardagbókum eða fyllti pær ekki rétt út. Til pess að lágmarka skekkjur voru matardagbækur 18\% pátttakenda til viðbótar ekki hafðar með í útreikningum vegna verulegrar vanskráningar. Pó orkuinntaka og neysla næringarefna hafi verið marktækt lægri hjá peim sem vanskráðu samanborið við aðra pátttakendur, reyndist samsetning mataræðisins hins vegar ekki marktækt frábrugðin. Neysla lýsis var jafnframt sambærileg. Pó ekki sé hægt að fullyrða um pað er pó hugsanlegt að neysla ákveðinna matvæla, eins og til dæmis sælgætis, hafi verið hlutfallslega meiri meðal peirra sem vanskráðu. Að öðru leyti voru peir sem vanskráðu ekki frábrugðnir öðrum pátttakendum.

Rétt er að minnast á nokkra aðra takmarkandi pætti í rannsókninni. Ekki var um handahófsúrtak að ræða og pess vegna er rannsóknarpýðið mögulega ekki einkennandi fyrir eldri Íslendinga. Auk pess var blóðprýstingur mældur með sjálfvirkum mæli en slíkir mælar eru taldir ónákvæmir samanborið við handvirka mæla. ${ }^{18}$ Priggja daga vegin fæðuskráning getur einnig verið ónákvæmt mat á mataræði, sérstaklega hjá fólki sem er ekki vanafast í mataræði. Með veginni fæðuskráningu er heldur ekki tekið tillit til árstíðabundinna sveiflna í mataræði.

Að lokum má álykta að lýsisneysla tengist lægri blóðprýstingi meðal eldra fólks og hafi á pann hátt mögulega jákvæð áhrif á heilsufar. Ef miðað er við neyslu á venjulegu fæði, og tekið tillit til lýsisneyslu en öðrum fæðubótarefnum sleppt, var stór hluti pátttakenda í áhættuhópi vegna skorts á D-vítamíni, B6-vítamíni, joði og járni.

\section{Pakkir}

Tæknipróunarsjóði RANNÍS og Rannsóknasjóði Háskóla Íslands er pakkað fyrir veittan fjárstuðning við framkvæmd rannsóknarinnar. 


\section{Heimildir}

1. American College of Sports Medicine, Chodzko-Zajko WJ Proctor DN, Fiatarone Singh MA, Minson CT, Nigg CR, et al. American College of Sports Medicine position stand Exercise and physical activity for older adults. Med Sci Sport Exerc 2009; 41: 1510-30.

2. Butler J, Kalogeropoulos AP, Georgiopoulou VV, BibbinsDomingo K, Najjar SS, Sutton-Tyrrell KC, et al. Systolic blood pressure and incident heart failure in the elderly. The Cardiovascular Health Study and the Health, Ageing and Body Composition Study. Heart 2011; 97: 1304-11.

3. Geleijnse JM, Giltay EJ, Grobbee DE, Donders AR, Kok FJ. Blood pressure response to fish oil supplementation: metaregression analysis of randomized trials. J Hypertens 2002; 20: 1493-9.

4. Nordic Nutrition Recommendations 2004, 4th edition. Nordic Council of Ministers, Copenhagen 2004.

5. Giles TD, Materson BJ, Cohn JN, Kostis JB. Definition and classification of hypertension: an update. J Clin Hypertens 2009; 11: 611-4.

6. Chobanian AV, Bakris GL, Black HR, Cushman WC, Green LA, Izzo Jr. JL, et al. Seventh report of the Joint National Committee on prevention, detection, evaluation, and treatment of high blood pressure. Hypertens 2003; 42: $1206-52$
7. Goldberg GR, Black AE, Jebb SA, Cole TJ, Murgatroyd PR, Coward WA, et al. Critical evaluation of energy intake data using fundamental principles of energy physiology: 1. Derivation of cut-off limits to identify under-recording. Eur J Clin Nutr 1991; 45: 569-81.

8. Black AE. Critical evaluation of energy intake using the Goldberg cut-off for energy intake: basal metabolic rate. A practical guide to its calculation, use and limitations. Int J Obes Relat Metab Disord 2000; 24: 1119-30.

9. Lührmann PM, Herbert BM, Neuhaüser-Berthold M Underreporting of energy intake in an elderly German population. Nutrition 2001; 17: 912-6.

10. Harris J, Benedict F. A biometric study of basal metabolism in man. Carnegie Institute of Washington, Washington DC 1919; publication no. 279.

11. Krenitsky J. Adjusted body weight, pro: evidence to support the use of adjusted body weight in calculating calorie requirements. Nutr Clin Pract 2005; 20: 468-73.

12. Shah B, Sucher K, Hollenbeck CB. Comparison of ideal body weight equations and published height-weight tables with body mass index tables for healthy adults in the United States. Nutr Clin Pract 2006; 21: 312-9.

13. Cabo J, Alonso R, Mata P. Omega-3 fatty acids and blood pressure. Br J Nutr 2012; 107 (SUPPL. 2): S195-S200.
14. Olafsdottir AS, Skuladottir GV, Thorsdottir I, Hauksdottir A, Thorgeirsdottir $\mathrm{H}$, Steingrimsdottir L. Relationship between high consumption of marine fatty acids in early pregnancy and hypertensive disorders in pregnancy. BJOG 2006; 113: 301-9.

15. porgeirsdóttir $\mathrm{H}$, Valgeirsdóttir $\mathrm{H}$, Gunnarsdóttir $\mathrm{I}_{\text {, }}$ Gísladóttir E, Gunnarsdóttir BE, Pórsdóttir I, et al. Hvað borða Íslendingar? Könnun á mataræði Íslendinga 2010-2011. Helstu niðurstöður. Embætti landlæknis, Matvælastofnun, Rannsóknarstofa í næringarfræði við Háskóla Íslands og Landspítala 2012.

16. O'Connor A, Benelam B. An update on UK Vitamin D intakes and status, and issues for food fortification and supplementation. Nutr Bull 2011; 36: 390-6.

17. Riediger ND, Moghadasian MH. Patterns of fruit and vegetable consumption and influence of sex, age and socio-demographic factors among Canadian elderly. J Am Coll Nutr 2008; 27: 306-13.

18. Skirton $\mathrm{H}$, Chamberlain W, Lawson C, Ryan H, Young E. A systematic review of variability and reliability of manual and automated blood pressure readings. J Clin Nurs 2011; 20: 602-14

\section{ENGLISH SUMMARY}

\section{Dietary habits and their association with blood pressure among elderly Icelandic people}

Arnarson $\mathrm{A}^{1}$, Geirsdottir $\mathrm{OG}^{2,5}$, Ramel $\mathrm{A}^{1,5}$, Jonsson $\mathrm{PV}^{2,3,4}$, Steingrimsdottir $\mathrm{L}^{1,5}$, Thorsdottir $\mathrm{I}^{1,5}$

Objective: Prevalence of hypertension, which is the most common risk factor for cardiovascular disease in elderly people, increases with age. The aim of the study was to investigate the association between diet and blood pressure in elderly lcelanders, with focus on cod liver oil, and to compare their diet to dietary guidelines.

Material and methods: Diet was assessed using three-day weighed food records and blood pressure was measured after a 12-hour-fast in 236, 65-91 years old, Icelanders living in the capital area of Iceland. 99 men (42\%) and 137 women (58\%) participated in the study.

Results: According to Nordic nutrition recommendations, intake of nutrients was above lower intake levels among the majority of participants. However, $19 \%$ were under this level for vitamin-D, 13\% for iodine, $17 \%$ of men for vitamin-B6, and $26 \%$ and $12 \%$ of men and women, respectively, for iron. Systolic blood pressure was inversely associated with cod liver oil intake, even when adjusted for age, body mass index, gender, and antihypertensive medications $(P=0.01)$. Intake of long-chain omega- 3 fatty acids correlated with blood pressure in a similar way. Other dietary factors were not associated with blood pressure.

Conclusion: The results indicate that intake of cod liver oil is associated with lower blood pressure among elderly people and may therefore have beneficial effects on health. A notable proportion of participants was at risk of vitamin $\mathrm{D}$, vitamin $\mathrm{B} 6$, iodine, and iron deficiency.

Key words: diet, elderly, omega-3 fatty acids, omega-3, cod liver oil, blood pressure, hypertension.

Correspondence: Atli Arnarson, atliarnar@gmail.is

${ }^{1}$ Unit for Nutrition Research, Landspitali National University Hospital, ${ }^{2}$ The Icelandic Gerontological Research Center, ${ }^{3}$ Faculty of medcine University of Iceland, ${ }^{4}$ Department of Geriatrics, Landspitali National University Hospital, ${ }^{5}$ Faculty of Food Science and Nutrition, University of Iceland. 